\title{
Ästhetisierung der Politik
}

\section{Dissertation zur Erlangung des Grades eines Doktors der Philosophie der Universität Bremen}

Diese Arbeit hat dem Promotionsausschuß Dr. phil. der Universität Bremen als Dissertation vorgelegen. An dem Promotionsverfahren haben Prof. Dr. Wolfgang Emmerich und Prof. Dr. Gert Sautermeister als Gutachter mitgewirkt. Das Kolloquium fand am 28. Juni 1977 statt. 
ISBN 978-3-476-99532-2

ISBN 978-3-476-99531-5 (eBook)

DOI 10.1007/978-3-476-99531-5 
INHALT

Einleitung. ............................. 1

Zum Begriff » Ästhetisierung ". Kleiner kunst-und geschichtsphilosophischer Streif-



Ästhetik, Kunstautonomie und Ästhetisierung . . . . . . . . . . . . . . . . . 12

Exkurs: Boris Arvatov und Walter Benjamin . . . . . . . . . . . . . 28

Ästhetisierung als Folge der Zerstörung des Gebrauchswerts. Zur Grundlegung einer Faschismustheorie aus der Perspektive des Subjekts . . . . . . . . . 33

Die faschistische Traditionslinie in der Arbeiterdichtung . . . . . . . . . . . . . 48

Die Werkleute auf Haus Nyland als Ausdruck imperialistischer Kulturrevolution 48

Der Weltkrieg als Revolutionsersatz. Zur Kriegslyrik der Arbeiterdichter . . . 68

Arbeit und Arbeiter in der Arbeiterdichtung der Weimarer Republik. Die Subjektivierung und Ästhetisierung gesellschaftlicher Objektivität . . . . . . . . . . 80

Der ohnmächtig-allmächtige Arbeiter. Zur nationalsozialistischen Arbeits-

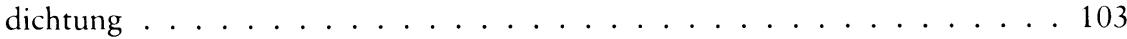

Der subjektive Faschismus im Spiegel von Massenromanen . . . . . . . . . . . 111

Die Krise des Alltagsbewußtseins (Bruno Nelissen Haken, Felix Riemkasten) 111

Der Alltag als Kampfplatz von Kommunismus und Faschismus . . . . . . . 123

Häuslichkeit als faschistisches Blendwerk . . . . . . . . . . . . . . . 123

Liebe und Politik . . . . . . . . . . . . . . . . . . . . . . . . 129

Feiern, vor allem: Weihnachten . . . . . . . . . . . . . . 131

Von Geselligkeit, Frohsinn und Natur . . . . . . . . . . . . . . . . . . 133

Religion und Politik . . . . . . . . . . . . . . . 138

Faschisierung als Identitätsverlust . . . . . . . . . . . . . . . . . . 143

Momente faschistischer Scheinidentität . . . . . . . . . . . . . . . . . 149

Idealismus ohne Ideale, Voluntarismus, Irrationalismus, Korruption . . . . 149

Die Zersetzung des Antikapitalismus in konterrevolutionäre Gewalt und revolutionären Schein . . . . . . . . . . . . . . . . 153

Literarische Qualität und politische Tendenz . . . . . . . . . . . . . . 163

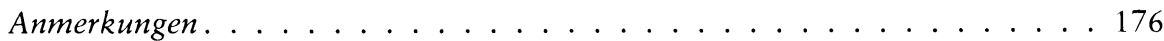

Literaturverzeichnis. . . . . . . . . . . . . . . . . . . . . 210

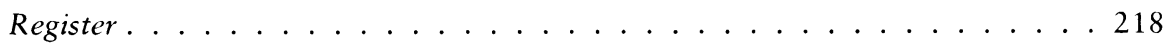

